\title{
USABILITY AND USEFULNESS FOR ONLINE SINGLE SUBMISSION SYSTEM IN INVESTMENT AND ONE-STOP INTEGRATED SERVICE OFFICE, SAMARINDA CITY
}

\author{
Edy Budiman ${ }^{1}$, Ummul Hairah ${ }^{2}$ \\ ${ }^{1,2}$ Department of Informatics Faculty of Engineering, Universitas Mulawarman, Indonesia \\ 1edy.budiman@fkti.unmul.ac.id
}

\begin{abstract}
The challenge of implementing the online service public system from the user side of the system is the acceptance and use of technology. User characteristics for accepting or rejecting the use of the system for various reasons (digital literacy) for the adoption of new technologies such as the Online Single Submission (OSS) system. The research purpose is to offer a theoretical model of the Technology Acceptance Model (TAM) to evaluate the use and acceptance of users to the OSS system at the Investment Service and One-Stop Integrated Service of the Samarinda City during the Covid-19 pandemic. The method used to measure the variable effects using Partial Least Square - Structural Equation Modeling (PLS-SEM) on perceived ease of use (usability) and perceived usefulness, behavior intention to use, and Attitude toward Using the Online Single Submission system. Based on the results of testing the hypothesis $\mathrm{HO}$ proposed is accepted. OSS system users find it useful to assist in completing work (licensing process). That perceived Ease of Use, Perceived Usefulness have a positive effect and significant on the Behaviour Intention to Use adopt the OSS system for users and have a goodness of fit.
\end{abstract}

Keywords: Online Single Submission; Technology Acceptance Model; Partial-Least-Square; One-Stop Integrated Service.

\section{INTRODUCTION}

Optimizing the use of information technology during the Covid-19 pandemic is the right thing to provide public services. One solution to increasing public service standards is the implementation of an online service system [1].

The challenge of implementing the online service system from the user side of the system is the acceptance and use of technology. User characteristics for accepting or rejecting the use of the system for various reasons (digital literacy problems) for the adoption of new technologies such as the Online Single Submission (OSS) system[2] as one of the innovations in licensing services from the Investment Service and One-Stop Integrated Services.

One-Stop Integrated Service is a licensing service whose management process starts from the submission stage to the final stage of issuing service documents through one door and in one place. During the Covid-19 pandemic, OSS systems are used to deliver service standards, service product delivery, requirements, mechanisms, procedures, costs, and timeframes, as well as for technical activities such as the registration process, completing files (data archiving) including taking queue numbers. Providing clear and up-to-date information will greatly assist users in obtaining clear information so that service users can adjust the time of arrival of users so as not to cause crowds in the service room.

The Indonesian Government's Large-Scale Social Restrictions Policy [3] has an impact on public service standards, particularly in the OSS system in its effect on user acceptance related to the perception usability (ease-to-use) and usefulness of the OSS system toward intention to use in their licensing process.

Various models of user technology acceptance of the available OSS system are applied[4], one of which is the technology acceptance model (TAM) that specifically assesses system performance in terms of user-perceived ease of use and perceived usefulness [5].

Various applied models in cases such as Acceptance Analysis of The East Java Province E- 
Procurement System Using TAM Method from Mas Odi and Erma Suryani[6]. Lijun Chen and Apetogbo Komlan Aklikokou in Determinants of Egovernment Adoption: Testing the Mediating Effects of Perceived Usefulness and Perceived Ease of Use [7], e-purchase intention of Taiwanese consumers: Sustainable mediation of perceived usefulness and perceived ease of use [8], and other.

The research purpose is to offer a theoretical model of the Technology Acceptance Model (TAM) to evaluate the use and acceptance of users to the OSS system at the Investment Service and OneStop Integrated Service of the Samarinda City during the Covid-19 pandemic. The method used to measure the variable effects using Partial Least Square - Structural Equation Modeling (PLS-SEM) on perceived ease of use and perceived usefulness, behavior intention to use, and Attitude toward Using the Online Single Submission system.

Research limitations have been carried out under the appropriate research guidelines, and the results have met the requirements of PLS-SEM testing as well as the support of previous theories and research. However, there are still limitations in field implementation. This limitation creates bias and inaccuracy so that it has the potential to influence the results of the study. Limitations that occur such as Limitations of the researcher to assist the respondents in filling out the questionnaire. This is due to the existence of a health protocol policy during the Covid-19 pandemic.

The implication, these results provide a new point of view that the TAM model becomes one of the recommended models for evaluating the acceptance and use of the OSS system. The results of the study serve as a reference for further studies to determine the factors that influence the acceptance and use of the OSS system.

\section{MethodolOGY}

\section{A. Design Model and Research Type}

The questions that will be answered in this research are what factors influence the acceptance and use of the OSS system. These questions will be answered using the TAM model and Partial Least Square-Structural Equation Modeling (PLS-SEM) to measure exogenous and endogenous variables.
This type of research is an explanatory study with a quantitative approach. The data obtained from the results of the research collected reveal the relationship of the existing variables. The purpose of the research design is to determine the effect of the independent variable (X) on the dependent variable (Y) and to test the formulation of the hypothesis. In the PLS-SEM model, the independent variables are known as exogenous or predictor variables. The exogenous variables in the study were usability (perception ease of use or PEU) and the perception of usefulness (PU).

An overview of the theoretical model design of use and user acceptance of the OSS system is presented in "Fig 1".

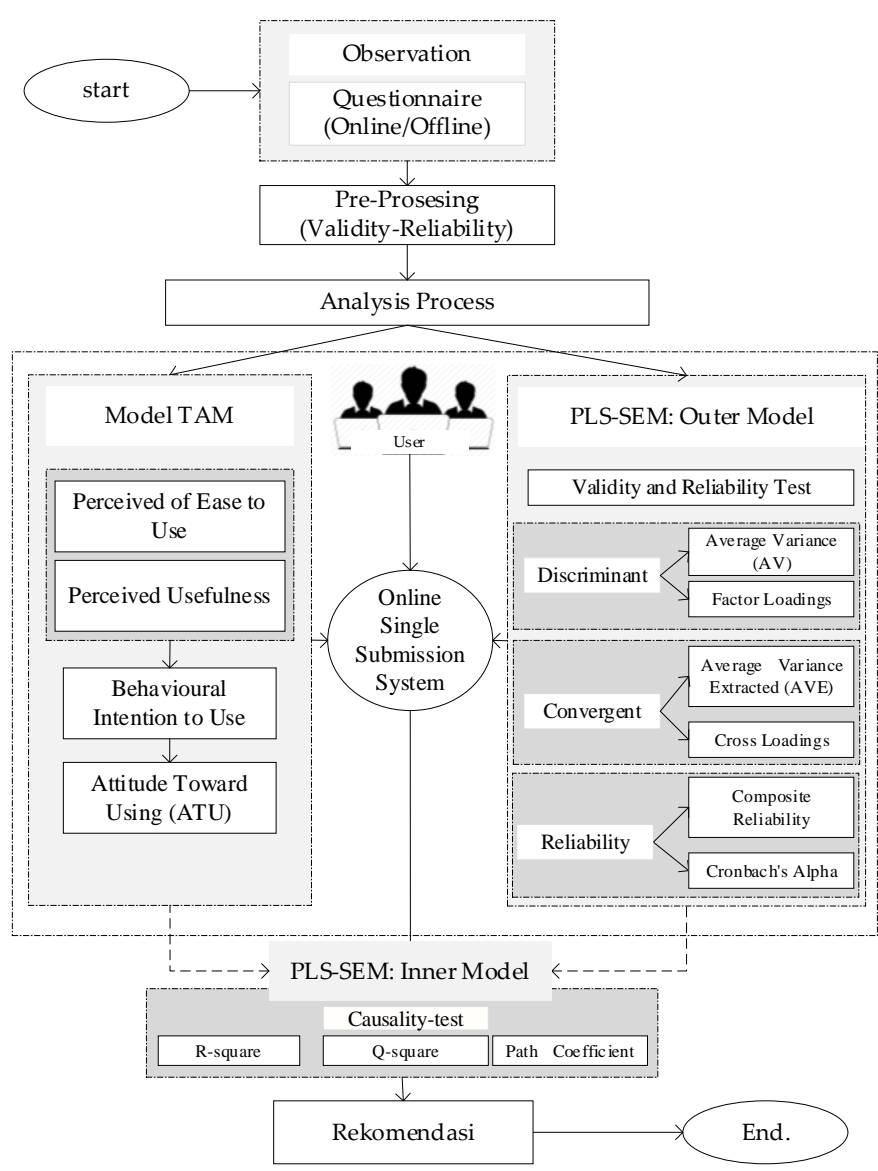

Fig. 1. model design of use and user acceptance for the OSS system

\section{B. Data Collection Methods}

Collecting data using the observation method through structured questionnaires distributed offline and online during the Covid-19 pandemic to OSS system users Investment and One-Stop Integrated Service Office Samarinda City. Literature studies 
are used from various sources of data and information; articles, books, and more. The sampling technique used was Saturated Sampling, that is, all samples or the entire community in processing permits using the OSS system within a period of 3 months (May to July 2020). The questionnaires obtained during the study were 167 respondents.

\section{Technology Acceptance Model}

The model of acceptance and use of the OSS system uses the Technology Acceptance Model (TAM) analysis model in "Fig 2".

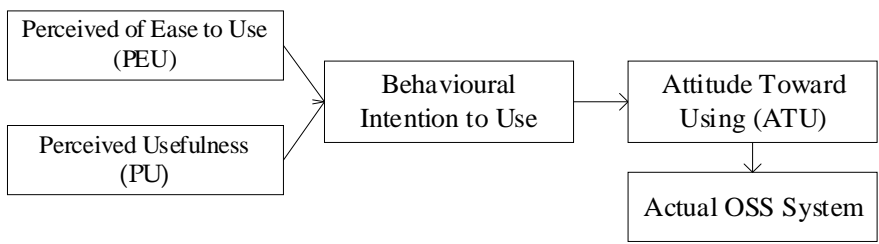

Fig. 2. Path for Technology Acceptance Model

The TAM model describes the user acceptance of technology which combines and develops multiple acceptance theories[9]. These theories, namely Theory of Reasoned Action (TRA), Theory of Planned Behavior (TPB), Motivational Model (MM), Theory of Planned Behavior (TPB), Combination of TAM and TPB theoretical models, Model of PC Utilization (MPCU) ), Innovation Diffusion Theory (IDT), and Social Cognitive Theory (SCT)[4].

The construct variables in the TAM method consist of Perceived Ease to Use (PEU), Perceived Usefulness (PU), Behavior Intention to Use (BIU), and Attitude Toward Using (ATU). the variable indicators are presented in Table 1.

\section{Data Analysis Methods}

Analysis of pre-processing and data processing using SmartPLS version 3.3.3 software for data consistency which includes the cleaning process for data: duplicates, missing and includes validity and reliability testing of instruments. Data analysis used descriptive and inferential statistics. The descriptive statistical analysis presents research data in the form of mean scores. Inferential analysis using PLS-SEM analysis technique using SmartPLS 3.3.3 software.
TABLE I

Variable and indicator of TAM

\begin{tabular}{|c|c|c|c|}
\hline & Definitions & Code & Indicators \\
\hline \multirow{4}{*}{ PEU } & \multirow{4}{*}{$\begin{array}{l}\text { Usability (Ease } \\
\text { of use) regarding } \\
\text { technology } \\
\text { (OSS system) }\end{array}$} & PEU.1 & Usability in work \\
\hline & & PEU.2 & $\begin{array}{l}\text { Help complete tasks } \\
\text { quickly (effectively) }\end{array}$ \\
\hline & & PEU.3 & $\begin{array}{l}\text { Increase work } \\
\text { productivity }\end{array}$ \\
\hline & & PEU.4 & $\begin{array}{l}\text { Improve work } \\
\text { efficiency }\end{array}$ \\
\hline \multirow{4}{*}{ PU } & \multirow{4}{*}{$\begin{array}{l}\text { The degree to } \\
\text { which users } \\
\text { believe adopting } \\
\text { technology will } \\
\text { assist improve } \\
\text { task completion } \\
\text { (performance) }\end{array}$} & PU.1 & $\begin{array}{l}\text { The OSS system is } \\
\text { easy to learn }\end{array}$ \\
\hline & & PU.2 & $\begin{array}{l}\text { User interaction with } \\
\text { the OSS system is } \\
\text { clear and easy to } \\
\text { understand }\end{array}$ \\
\hline & & PU.3 & $\begin{array}{l}\text { The OSS system is } \\
\text { easy to use }\end{array}$ \\
\hline & & PU.4 & $\begin{array}{l}\text { Easy for users to use } \\
\text { the OSS system }\end{array}$ \\
\hline \multirow{3}{*}{$\mathrm{BIU}$} & \multirow{3}{*}{$\begin{array}{l}\text { The degree to } \\
\text { which a person } \\
\text { has formulated a } \\
\text { conscious plan } \\
\text { using or not } \\
\text { some defined } \\
\text { future behavior. }\end{array}$} & BIU.1 & $\begin{array}{l}\text { Intention to continue } \\
\text { using the OSS } \\
\text { system in the future }\end{array}$ \\
\hline & & BIU.2 & $\begin{array}{l}\text { Willingness to try to } \\
\text { use technology in life }\end{array}$ \\
\hline & & BIU.3 & $\begin{array}{l}\text { Plans to continue } \\
\text { using technology }\end{array}$ \\
\hline \multirow{3}{*}{ ATU } & \multirow{3}{*}{$\begin{array}{l}\text { Individual } \\
\text { positive or } \\
\text { negative feelings } \\
\text { about the } \\
\text { behavior of using } \\
\text { the OSS system }\end{array}$} & ATU.1 & $\begin{array}{l}\text { Frequency of use of } \\
\text { technology }\end{array}$ \\
\hline & & ATU.2 & $\begin{array}{l}\text { Interested in using } \\
\text { the services available } \\
\text { in the OSS system }\end{array}$ \\
\hline & & ATU.3 & $\begin{array}{l}\text { Ready to use the } \\
\text { services available in } \\
\text { the OSS system }\end{array}$ \\
\hline
\end{tabular}

This research uses a model of causality or effect relationships. Thus, to test the proposed hypothesis, the PLS-SEM analysis technique is used which is operated through the SmartPLS 3.3.3 program. Partial Least Squares is an analysis of structural equations (Structural Equation Modeling - SEM) based on variants that can simultaneously test the measurement model as well as test the structural model[10].

The measurement model (outer model) is used to test the validity and reliability, while the structural model is used to test the causality. The use of PLSSEM in this study was used to test and measure the direct and indirect effects of the perceived ease (usability) and usefulness, intention, and usage behavior variables. "Fig. 3" shows the proposed 
PLS path diagram model.

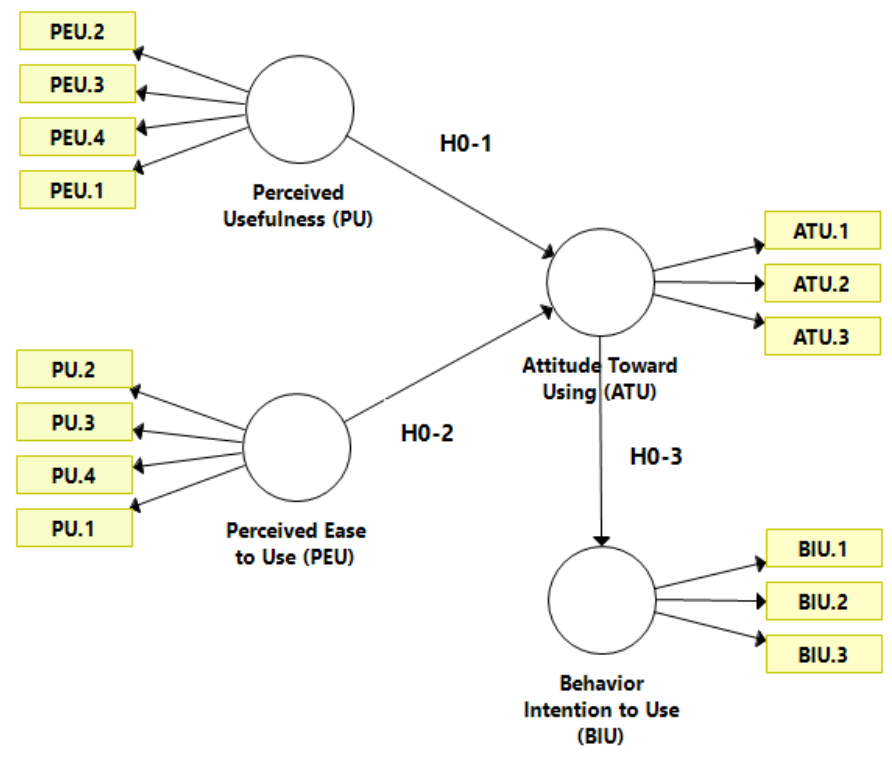

Fig. 3 Path PLS-SEM for TAM of OSS System

PLS-SEM analysis consists of 2 sub-models, namely: inner model and outer model. The outer model defines how each block or indicator relates to its latent variable. According to Armin Monecke and Friedrich Leisch the basic equation model of the outer model [11] as follows Equation for the exogenous latent construct $(\mathrm{X})$ and the endogenous latent construct $(\mathrm{Y})$ :

$$
\begin{aligned}
& \mathrm{X}=\lambda \mathrm{X}-\xi+\delta \\
& \mathrm{Y}=\lambda \mathrm{Y} \eta+\varepsilon
\end{aligned}
$$

where: $\lambda$ (lamda) factor weight between latent variable and its indicator, $\xi$ (Ksi) exogenous latent variable, $\varepsilon$ (epsilon) endogenous indicator error measurement, $\eta$ (eta) endogenous latent variable and $\delta$ (delta) exogenous indicator error measurement.

\section{E. Testing Methods}

Testing for the outer model uses the Validity Test, namely convergent validity and discriminant validity. Convergent validity was tested throughloading factor parameters and Average Variance Extracted (AVE) values. Measurements can be categorized as having convergent validity if the loading factor value is more than 0.7 and the AVE value is more than $0.5[12]$ equation use "(3)".

$$
A V E=\frac{\sum \lambda_{i}^{2}}{\sum \lambda_{i}^{2}+\sum_{i} \operatorname{var}\left(\varepsilon_{i}\right)}
$$

Discriminant validity is determined by the crossloading value of each variable. The measurement is categorized as having discriminant validity if it has a cross-loading value of more than 0.7 . Discriminant validity is determined by the crossloading value of each variable. The measurement is categorized as having discriminant validity if it has a cross-loading value of more than 0.7 . Reliability Test, reliability testing based on Cronbach's alpha value must be more than 0.6 and the composite reliability value must be more than 0.7 . The composite reliability value shows the measure of the real reliability value of a variable while Cronbach's alpha shows the measure of the lowest reliability value of a variable with equation use “(4)".

$$
\text { Composite Reliability }=\frac{\left(\sum \lambda \mathrm{i}\right)^{2}}{\left(\sum \lambda \mathrm{i}\right)^{2}+\sum_{i} \operatorname{var}\left(\varepsilon_{i}\right)}
$$

Testing on the inner model or structural model to test the relationship between latent constructs. The inner model includes inner relations, structural models, and the substantive theory describing the relationship between latent variables based on the substantive theory. The inner model is tested by looking at the value of the R-square, Q-square, and path coefficient (path coefficient) to obtain information on how much the dependent latent variable is affected by the independent latent variable, as well as the significant (sig.) test for the sig. value of the relationship/effect the independent variables $(\mathrm{X})$ sig. to the dependent variable (Y). Significant means that the effect that occurs can apply to the population (can be generalized). As for the basis for decision making in the analysis of the significant value (Sig.) are:

If the significant value (Sig.) is less than the probability of 0.05 (P-value $<0.05$ ) implies that there is an effect of variable $(\mathrm{X})$ on variable $(\mathrm{Y})$.

If the significant value (Sig.) is greater than the probability 0.05 (P-value $>0.05$ ), it means that there is no effect of the variable $(\mathrm{X})$ on the variable (Y).

Q-square test, in PLS-SEM, is used for predictive 
relevancy in the constructive model. In the goodness of fit assessment, it is known through the Q-square value to measure how well the observation value generated by the model and also its parameter estimates. The equation uses "(5)".

$$
\mathrm{Q}^{2}=1-\left(1-\mathrm{R} 1^{2}\right)\left(1-\mathrm{R} 2^{2}\right) \ldots\left(1-\mathrm{Rp}^{2}\right)
$$

where: $\mathrm{R} 1^{2}, \mathrm{R} 2^{2} . . \mathrm{Rp}^{2}$ is the $\mathrm{R}$-square of the endogenous variables in the model. While $\mathrm{Q}^{2}$ the total coefficient of determination in the path analysis. Hypothesis testing is related to testing the relationship between variables. The measure of significance was used to compare the value of $\mathrm{t}$ table and t-statistic. If the T-statistic value is greater than the T-table value (T-statistic > T-table), so it can be concluded that $\mathrm{HO}$ is rejected and $\mathrm{Ha}$ is accepted, which means that there is an effect of variable $(\mathrm{X})$ on variable $(\mathrm{Y})$ or vice-versa.

\section{RESUltS AND DisCUSSION}

This study offers a theoretical model of the use and acceptance of technology for the OSS system during the Covid-19 pandemic using the TAM method to determine the perceived ease of use (usability), the perceived usefulness (usability) of intent, and the behavior of using the OSS system using the PLS-SEM measurement model.

The results of data collection through structured questionnaires obtained 167 items, after going through pre-processing the complete questionnaire data were filled with 158 respondents (useable rate $94.6 \%)$.

Instrument testing through validity and reliability tests used 158 samples $(\mathrm{N}=158)$ with 14 items. Based on the number of $\mathrm{N}$ is 158 at a sig level of $1 \%$, the value of the r-table is 0.210 . The r-value of the table will be compared with the calculated $r$ value and the values for all items r-count > r-table are valid status. Furthermore, for reliability testing, the Cronbach's alpha value was 0.963 , which indicates that the reliability test results of the r-count value of $0.963>0.210$ (r-table).

\section{A. Outer Model Testing}

Validity and reliability analysis using PLS-SEM was evaluated on the outer model. The validity of the measurement consists of convergent validity and discriminant validity. Determined using the outer and cross-loading factor parameter $(>0.7)$, and the value of Average Variance Extracted AVE > 0.5 equations use "(3)". The result of the correlation between the indicator and the construct shows the outer loading value $>0.7$. The value of the outer loading model is seen in Table II.

TABLE II

Outer Loadings and Cross Loadings

\begin{tabular}{|l|c|c|c|c|}
\hline \multicolumn{1}{|c|}{ Variabel } & ATU & \multicolumn{1}{c|}{ BIU } & PEU & \multicolumn{1}{c|}{ PU } \\
\hline ATU.1 & 0.796 & 0.553 & 0.575 & 0.685 \\
\hline ATU.2 & 0.913 & 0.602 & 0.780 & 0.874 \\
\hline ATU.3 & 0.845 & 0.827 & 0.811 & 0.687 \\
\hline BIU.1 & 0.620 & 0.776 & 0.510 & 0.550 \\
\hline BIU.2 & 0.716 & 0.910 & 0.678 & 0.556 \\
\hline BIU.3 & 0.647 & 0.839 & 0.601 & 0.476 \\
\hline PU.1 & 0.764 & 0.470 & 0.810 & 0.780 \\
\hline PU.2 & 0.620 & 0.626 & 0.798 & 0.573 \\
\hline PU.3 & 0.764 & 0.621 & 0.927 & 0.721 \\
\hline PU.4 & 0.752 & 0.708 & 0.859 & 0.672 \\
\hline PEU.1 & 0.612 & 0.481 & 0.629 & 0.795 \\
\hline PEU.2 & 0.643 & 0.461 & 0.519 & 0.780 \\
\hline PEU.3 & 0.723 & 0.504 & 0.640 & 0.787 \\
\hline PEU.4 & 0.819 & 0.555 & 0.798 & 0.853 \\
\hline
\end{tabular}

The convergent validity test is seen from the AVE value using equation 3 . The variables in this study already have an AVE value $>0.5$. As shown in Tabel III.

TABLE III

Construct Reliability and Validity

\begin{tabular}{|l|r|r|r|}
\cline { 2 - 4 } \multicolumn{1}{c|}{} & \multicolumn{1}{c|}{$\begin{array}{c}\text { Cronbach's } \\
\text { Alpha }\end{array}$} & $\begin{array}{r}\text { Composite } \\
\text { Reliability }\end{array}$ & $\begin{array}{c}\text { Average Variance } \\
\text { Extracted (AVE) }\end{array}$ \\
\hline ATU & 0.812 & 0.889 & 0.727 \\
\hline BIU & 0.795 & 0.880 & 0.711 \\
\hline PEU & 0.871 & 0.912 & 0.722 \\
\hline PU & 0.819 & 0.880 & 0.647 \\
\hline
\end{tabular}

Composite reliability tests the reliability value of indicators on a variable. A variable meets composite reliability if it has a value $>0.7$. Reliability testing is also seen from Cronbach's alpha value in Table III showing a value above 0.6 which proves that the measurement is reliable.

\section{B. Inner Model Testing}

Evaluate the inner model or test the structural 
model to see the direct and indirect effects between variables. Evaluation of the inner model with PLSSEM begins with the see of the R-square value. Based on data processing with SmartPLS 3.3.3, the $\mathrm{R}-$ Square value is generated in Table IV.

TABLE IV

R-Square and R-Square Adjusted

\begin{tabular}{|l|r|r|}
\hline & R Square & \multicolumn{2}{|l|}{$\begin{array}{l}\text { R Square } \\
\text { Adjusted }\end{array}$} \\
\hline Attitude Toward Using (ATU) & 0.832 & 0.83 \\
\hline Behavior Intention to Use (BIU) & 0.617 & 0.614 \\
\hline
\end{tabular}

Table IV shows that the R-square value for the variable Behavior Intention to Use (BIU) is 0.617. This means that the percentage of the influence of Perceived Ease to Use (usability), Perceived Usefulness on BIU is $61.7 \%$, while the remaining $38.3 \%$ is influenced by other factors. Furthermore, the R-square value for the variable Attitude Toward Using (ATU) is 0.832. This means that the percentage of influence is $83.2 \%$, while the remaining $16.8 \%$ is influenced by other factors. In the assessment of goodness of fit, it can be seen through the value of $\mathrm{Q}^{2}$. The value of $\mathrm{Q}^{2}$ has the same meaning as the coefficient of determination (R-Square) in regression analysis, where the higher the R-Square, the model can be said to be more fit with the data. Calculation of the value of Q2 use "(5)" obtained a value of 0.9357 , meaning that the magnitude of the diversity of the research data can be explained by the structural model developed in this study amounting to $93.5 \%$. Based on these results, the structural model in the study has a goodness of fit.

The next evaluation of the inner model on the path diagram shows how much influence the independent variable has on the dependent variable. "Fig. 4" is the path diagram in the model.

Hypothesis test after the data meets the measurement requirements, can be continued by performing the bootstrapping method on SmartPLS 3.3.3. The bootstrapping method is a procedure of taking new samples repeatedly as many as $\mathrm{N}$ new samples from the original data of size $n$, where for a new sample the sample points are taken from the original data one by one up to $\mathrm{n}$ times by taking. For the simultaneous test, the T-statistic test is used which is intended to test the significance of the effect of the exogenous variables $\mathrm{X}$ as a whole on the endogenous variable $\mathrm{Y}$. The test is by comparing the $\mathrm{T}$ value generated from the $\mathrm{T}$ statistic calculation with the T-table value. The null hypothesis will be accepted if the T-statistic value is greater than the T-table value ( $\mathrm{T}$-statistic $>\mathrm{T}$-table).

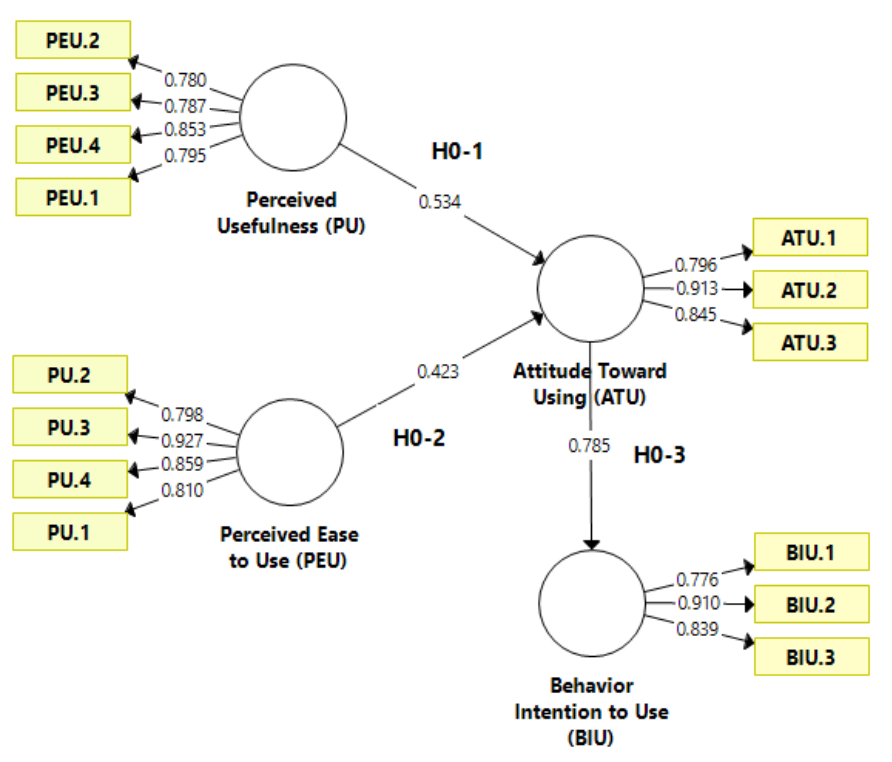

Fig. 4 Path Diagram Inner Model

The T-table value obtained based on the sig level of 0.05 with the number of observations 158 , is $1.65356(\mathrm{~T}$-table $=1.65356)$. Table $\mathrm{V}$ below is the result of the T-statistic test.

TABLE V

Hypothesis Statistic and P-value

\begin{tabular}{|c|c|c|c|}
\hline $\begin{array}{c}\text { Hyphothesis } \\
\text { Statistic }\end{array}$ & $\begin{array}{c}\text { Original } \\
\text { Sample }\end{array}$ & T-statistic & P-value \\
\hline $\mathrm{ATU} \rightarrow \mathrm{BIU}$ & 0.785 & 15.154 & 0.000 \\
\hline $\mathrm{PEU} \rightarrow \mathrm{ATU}$ & 0.423 & 3.290 & 0.001 \\
\hline $\mathrm{PEU} \rightarrow \mathrm{BIU}$ & 0.332 & 3.324 & 0.001 \\
\hline $\mathrm{PU} \rightarrow \mathrm{ATU}$ & 0.534 & 4.639 & 0.000 \\
\hline $\mathrm{PU} \rightarrow \mathrm{BIU}$ & 0.420 & 4.179 & 0.000 \\
\hline
\end{tabular}

Based on the equation model In "Fig. 4", structural equations are made in the path diagram, and statistical hypothesis testing for testing each research hypothesis (Table V) shows that the Hypotheses H01, H0.2, and H0.3 obtained Tstatistic values $>\mathrm{T}$-table, then the null hypothesis (H0) is accepted "there is a positive influence independently of the independent variable on the dependent variables. 
As for the basis for decision making in the analysis of the significant value (Sig.), then, If the Sig. P-value is less than the probability of 0.05 , which implies that there is an effect of variable $(\mathrm{X})$ on variable (Y). Because the $\mathrm{P}$-value in Table $\mathrm{V}$ on each variable is obtained in the range of 0.000 0.001 (P-value) is smaller than the probability of $0.05(0.000$ or $0.001<0.05)$, it is concluded that $\mathrm{H} 0$ is rejected and $\mathrm{Ha}$ is accepted, which means that there is a significant effect of variable (X) on variable $(\mathrm{Y})$.

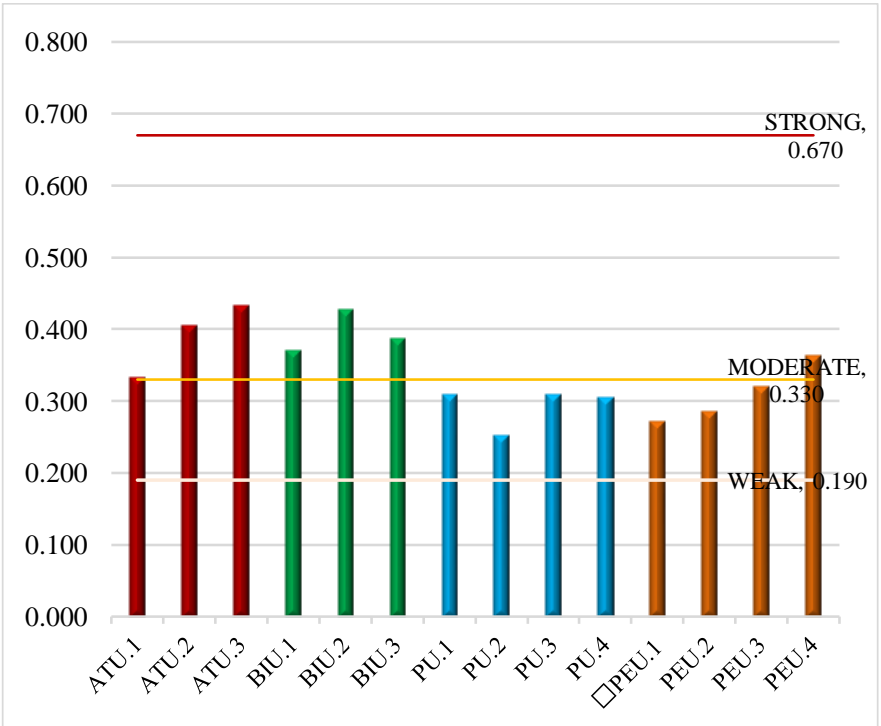

Fig. 5 Path Coefficients for Inner Weights

Meanwhile, the strong influence of the relationship between variables is seen from the inner weight value. If the inner weight value shows the number 0.67 ; 0.33 ; and 0.19 indicates that the influence between variables is strong, moderate, and weak.

\section{Discussion}

This study tested the TAM model on the influence of the variable usability (perceived ease to use) and perceived usefulness on the intention and behavior of using the OSS system using the PLSSEM analysis technique, so the findings of hypothesis testing were obtained:

The results of the hypothesis testing that the proposed $\mathrm{H} 0$ (H0.1, H0.2, and H0.3) are accepted. OSS system users feel the ease of use and usefulness of the OSS system in assisting task completion (licensing process), that perceived ease to use and perceived usefulness have a positive and significant effect on the intention to adopt the OSS system.

Another finding obtained in testing the Attitude Toward Using (ATU) variable on Behavior Intention to Use (BIU), this test explains that the influence of ATU moderates PEU and PU in reinforcing BIU.

The results of the R-square test show that there are still variables outside the model that has the potential to affect the acceptance and use of the OSS system. The percentage of Behavior Intention to Use is $61.7 \%$, while the remaining $38.3 \%$ is influenced by other factors. In the assessment of goodness of fit through the value of Q2, a value of 0.9357 was obtained, meaning that the magnitude of the diversity of the research data could be explained by the structural model developed in this study amounting to $93.57 \%$. Based on these results, the structural model in the applied research has a good fit.

\section{CONCLUSION}

This study has applied the Technology Acceptance Model to assess the level of perceived ease to use and perceived usefulness for users of the Online Single Submission system using Partial Least Square-Structural Equation Modeling analysis with SmartPLS version 3.3.3 software.

Application TAM model results concluded that there was a positive and significant effect of usability (perceived ease to use) and perceived usefulness variables on the intention and behavior of using the OSS system, individually or collectively. This explains that OSS system users feel the ease of use (usability) and usefulness of the OSS system in assisting the completion of licensing arrangements, that this perception will encourage trust and use interest in performing any service and the usability when using the OSS system and will certainly return to using the OSS System in the future. In the goodness of fit assessment From the developed TAM structural model, a good fit value of $93.57 \%$ was obtained. it is also shown in the potential influence of variables outside the model of $61.7 \%$, while the remaining $38.3 \%$ is influenced by other factors. So related to these results indicate the author to examine more widely the influence of 
factors of other variables outside of research in the future.

Implication: The study results provide a new perspective that the TAM model is expected to be a reference model for future studies to determine the factors that affect the acceptance and use of the OSS system. It is possible to identify other variables outside of this study that affects acceptance and use.

Recommendations, the DPMPTSP of Samarinda City continues to reinforce Attitude Toward Using to improve Behavior Intention to Use.

\section{ACKNOWLEDGMENT}

Thank you to the Investment and One-Stop Integrated Service Office (DPMPTSP), Government of Samarinda City for providing material support and research materials for the OSS system. Thanks are also conveyed to respondents who have provided feedback and ratings related to this research.

\section{REFERENCES}

[1] W. He, Z. (Justin) Zhang, and W. Li, "Information technology solutions, challenges, and suggestions for tackling the COVID-19 pandemic," Int. J. Inf. Manage., vol. 57: 102287, 2021, doi: 10.1016/j.ijinfomgt.2020.102287.

[2] Lembaga OSS BKPM, "Online Single Submission," oss.go.id, 2021. https://oss.go.id/portal/.

[3] Peraturan Pemerintah RI, Pembatasan Sosial Berskala Besar dalam Rangka Percepatan Penanganan Corona Virus Disease 2019 (COVID-19). Republik Indonesia, 2020, p. PP Nomor 21 Tahun 2020.

[4] P. Lai, "The Literature Review of Technology Adoption Models and Theories for the Novelty Technology," J. Inf. Syst. Technol. Manag., 2017, doi: 10.4301/s180717752017000100002.

[5] F. D. Davis, "Perceived usefulness, perceived ease of use, and user acceptance of information technology," MIS $Q$. Manag. Inf. Syst., 1989, doi: 10.2307/249008.

[6] M. Odi and E. Suryani, "Acceptance Analysis of The East Java Province E-Procurement System Using TAM Method," IPTEK J. Technol. Sci., 2020, doi: 10.12962/j20882033.v31i2.5641.

[7] L. Chen and A. K. Aklikokou, "Determinants of Egovernment Adoption: Testing the Mediating Effects of Perceived Usefulness and Perceived Ease of Use," Int. J. Public Adm., 2020, doi: 10.1080/01900692.2019.1660989.

[8] M. Moslehpour, V. K. Pham, W. K. Wong, and I. Bilgiçli, "e-purchase intention of Taiwanese consumers: Sustainable mediation of perceived usefulness and perceived ease of use," Sustain., 2018, doi: $10.3390 /$ su10010234.

[9] V. Venkatesh and F. D. Davis, "A model of the antecedents of perceived ease of use: Development and test," Decis. Sci., 1996, doi: 10.1111/j.15405915.1996.tb00860.x.

[10] K. K. K.-K. Wong, "28/05 - Partial Least Squares Structural Equation Modeling (PLS-SEM) Techniques Using SmartPLS," Mark. Bull., 2013.

[11] A. Monecke and F. Leisch, "SemPLS: Structural equation modeling using partial least squares," J. Stat. Softw., 2012, doi: 10.18637/jss.v048.i03.

[12] C. M. Ringle, M. Sarstedt, R. Mitchell, and S. P. Gudergan, "Partial least squares structural equation modeling in HRM research," Int. J. Hum. Resour. Manag., 2020, doi: 10.1080/09585192.2017.1416655. 